\title{
Managing Workload of Academic Staff for Job Effectiveness in Nigerian Universities: A Study of University of Port Harcourt in South-South Geopolitical Zone of Nigeria
}

\author{
Osaat Dinah Sunday ${ }^{1, *}$, Ekechukwu Rosemary ${ }^{2}$ \\ ${ }^{I}$ Department of Educational Management, Faculty of Education, University of Port Harcourt \\ ${ }^{2}$ Department of Educational Psychology, Guidance \& Counseling, Faculty of Education, University of Port \\ Harcourt \\ *Corresponding Author: Osaat Dinah Sunday, Department of Educational Management, Faculty of \\ Education. Universitv of Port Harcourt
}

\begin{abstract}
The study was aimed at investigating strategies for managing workload among lecturers in Nigerian universities. The design for the study was a descriptive survey. The population consisted of all the university lecturers in the south-south zone of Nigeria but was limited to university of Port Harcourt with a population of 400 lecturers. The stratified random sampling technique was used in selecting the study sample of 80 lecturers of different departments who responded to researchers' structured questionnaire tagged 'Management of Work Load among Universities Lecturers Questionnaire' (MAWLULQ). The instrument was based on a 4 point likert type scale with a reliability index of 0.78. Mean scores and standard deviation were used to answer the research questions. The findings showed that Lecturers perform so many tasks that are heavily loaded and the extent of influence of the workload as perceived by lecturers on their performance is high. The study revealed the coping strategies to be adopted in managing workload and related stress among lecturers which are: managing time appropriately, prioritizing the various works, always taking a short break in whatever work one does, appointment of lecturers into various offices should be well distributed, analysis of one's responsibilities adequately, adequate payment of overtime allowance to lecturers to enhance regular health checkups. The study therefore concludes that if these strategies are adhered to by both lecturers and the administration, that workload would be managed to a great extent and Nigerian lecturers would work and live to work again.
\end{abstract}

\section{INTRODUCTION}

Man's nature is that of working and without it the scripture says man should not eat. Through work God created the earth for six days and rested on the $7^{\text {th }}$ day. Though one cannot run away from work but the need to work and be conscious of the workload, its accompany stress and related job stress problems cannot be overemphasized. There is need to work and live to work another day.

Workloads are the duties or all the tasks carried out by workers in the course of their activities in their work place. Relating it to the lecturers, workloads are professional and non-professional duties carried out by the lecturers in the course of their activities in the instruction of students.

Lecturers are the greatest assets as well as major stakeholders in the university industry. Their main work is to teach and bring up the young generation of students to acquire skills and knowledge for growth and development. Teaching is a difficult task and demands serious commitment to be effective. Teaching involves adequate preparation of what to be taught through researches, regularity and punctuality to the class to implement what had been prepared. Teaching extends to evaluating the students through test, assignments and examinations, and particularly teaching extends to marking of examination scripts and production of results.

Other than these, lecturers are also exposed to variety of other duties some of which are complex and sometimes conflicting with their primary roles as teachers and academic staff. They are exposed to doing so many works almost at the same time with the teaching job which is primary. Some of which are examination officers, chart coordinators, directors, head of departments, deans, provost, project supervisors, at undergraduate and graduate levels, attending conferences, and publication of papers, 
teach very large classes as against NUC recommendation of 12 students to 1 lecturer (ASUU,2010). Most often these additional works tend to enlarge the workload of lecturers and make the load excessive. The resultant effect is the accompanying stress with its attendant health problems.

The extent of lecturers efficiency and effectiveness in their primary responsibility most often may not be guaranteed in the face of all these workload and their accompany stress. Though it is not entirely possible to rule stress out of any work yet, much stress could be caused by much work load and this can lead to so many dangers. In fact according to the American Psychological Association (2002), one of the things that causes stress among workers is overwork (excess work load)

Today researchers have proven that job related stress has negative effect on the individual. Stress has been proven to be a major contributor to some diseases that can impede the individual from achieving work effectiveness such as cardiac arrest, mental disorder, andhypertension. Apart from the inability to achieve work effectiveness these diseases can out rightly lead to death. A lot of sicknesses and deaths have been observed happening among university lecturers especially University of Port Harcourt. The authors are of the assumption that much of these sicknesses leading to ineffectiveness on the part of the lecturers could be responsible for poor academic achievement by the students thereby leading to cheating in examination to make their ways out of the system. The various deaths also among lecturers could be as a result of stressful situations arising from workload of lecturers. The need therefore to minimize this ugly trend in the system cannot be over emphasized. Effective management of workload could go a long way in reducing stress and its attendant's health problems thereby making the lecturers effective in attending to their responsibilities. The focus of this paper is therefore to investigate ways to manage workload of academic staff of universities to enhance job effectiveness.

One thing is to work and the other is to achieve effectiveness in such a work. Ordinarily when there is a normal workload, there is the tendency that a worker would achieve, but when the workload is much or excess in quantity and quality there is the likelihood that the worker may not perform well. No wonder Ignarson, Klemlewz, Bearis, Barrick, Carthy and Wilikinan (2005) reported that almost all teachers describe their workload as heavy and that at certain peak periods when their workload exceeds their capacity to manage, their teaching effectiveness and efficiency are negatively affected. In fact according to them, excess workload leading to stress causes lack of concentration which in turn affects level of performance. in line with this findings, Ekechukwu, and Isiguzo (2016), opined that stress and excess workload leads to inefficiency and death.

Much workload with limited times also leads to frustration. Muchinsly (2003) reported that frustration is expressed with the additional demands on time outside work which impinges on family and personal life. That most often workers carry over official duties to the home which also result to work/ family conflict. So balancing them according to Orluwene (2013) leads to frustration. A frustrated person cannot be effective. When the home front is affected, the lecturer is insecure and on the verge of burnout. Ekechukwu (2016)

Overload of work can also lead to development of deviant behavior among workers. According to Porath (2000) such deviant behaviors include lateness, absenteeism, poor decision making, bad judgment, nagging, sleeping on duty, insults, threats, sabotage, physical violence, and burnout.

Too much work in quantity and quality that demand thinking can also lead to restlessness and sleeplessness in the bid to accomplish the tasks. It may also lead to role conflict, frustration, emotional exhaustion, cynicism and poor personal accomplishment, which are symptoms of burnout. (Ekechukwu, 2010).Something has to be done. Against this background has the researcher decided to investigate ways to manage workload among university lecturers so that they could live to work another day. However few concepts have to be examined.

\section{Statement of Problem}

When it comes to student learning and achievement the lecturers are at the centre stage. Though other factors like student emotional stability and poor infrastructural facilities play their roles against students' achievement, the roles of the teachers matter a lot. The authors are of the assumption that the poor performance of students in their examinations, leading to students engaging in examination malpractice to get their ways out of the school is a testimony that enough has not been done by the 
teachers. If lecturers really drill the students the way it ought to be, would there be such menace in the university system? Could it not be that lecturers do not attend to students as required due to much workload on their parts? Could it not also be that the rampant sicknesses and sudden deaths among lecturers especially in university of Port Harcourt is as a result of work load and its attendants stress? Is there nothing to be done to manage this problem of workload so that lecturers would work and live to work another day? The problem of this study therefore is to investigate ways to manage work load among lecturers so that they can be effective in doing their primary job of teaching.

\section{AIM AND OBJECTIVES OF THE STUDY}

The aim of the study is to investigate ways to manage workload among universities' lecturers for effective productivity. Specifically the objectives are to;

- Identify the various academic works and activities engaged by lecturers in universities.

- To determine lecturers' perception on the extent their workload influences their job effectiveness.

- To determine coping strategies that can be adopted to manage work load among lecturers.

\subsection{Research Questions}

The following research questions guided the study

- What are the various workloads performed by lecturers in universities?

- What is the extent of influence of workload on job performance as perceived by lecturers?

- What coping strategies can be adopted to manage workload among lecturers in universities?

\section{Methodology}

The design for the study was a descriptive survey. The population consisted of all the universities in the south-south zone of Nigeria but was limited to university of Port Harcourt with a population of 400 lecturers. The stratified random sampling technique was used in selecting the study sample of 80 lecturers from different departments who responded to a structured questionnaire tagged: 'Management of Work Load among Universities Lecturers Questionnaire' (MAWLULQ). The instrument was based on a 4 point likert type scale with a reliability index of 0.78 . Mean scores and standard deviation were used to answer the research questions. The criterion mean of 2.5 was used to take decisions on the means responses from the respondents.

\section{RESULTS AND DISCUSSIONS}

\subsection{Research Question 1}

What are the various workloads performed by lecturers in universities?

Table 1: Mean analysis on the types of workload lecturers perform

\begin{tabular}{|l|l|l|l|l|l|l|l|}
\hline $\mathbf{S} / \mathbf{N}$ & \multicolumn{1}{|c|}{ Items } & SA & \multicolumn{1}{|c|}{ A } & \multicolumn{1}{|c|}{$\mathbf{D}$} & $\mathbf{S D}$ & \multicolumn{1}{|c|}{ X } & \multicolumn{1}{|c|}{ Decision } \\
\hline 1 & Planning what to teach on regular basis & 87 & 73 & 0 & 0 & 3.54 & Agreed \\
\hline 2 & Teaching very large classes & 41 & 69 & 30 & 20 & 2.82 & Agreed \\
\hline 3 & Conducting test and examination for large number of classes & 50 & 80 & 20 & 10 & 3.06 & Agreed \\
\hline 4 & $\begin{array}{l}\text { Invigilating students examinations under tension due to poor } \\
\text { accommodation }\end{array}$ & 70 & 60 & 25 & 5 & 3.22 & Agreed \\
\hline 5 & Producing students' results within limited time & 100 & 60 & 0 & 0 & 3.63 & Agreed \\
\hline 6 & Attending to staff meetings on regular basis & 40 & 50 & 40 & 30 & 2.63 & Agreed \\
\hline 7 & Attending seminars for students & 60 & 70 & 20 & 10 & 3.13 & Agreed \\
\hline 8 & Supervising undergraduate's projects within limited time & 50 & 80 & 20 & 10 & 3.19 & Agreed \\
\hline 9 & Supervising post graduate projects within limited time & 60 & 80 & 10 & 10 & 2.59 & Agreed \\
\hline 10 & Attending to project proposal defence on regular basis & 45 & 35 & 50 & 30 & 3.33 & Agreed \\
\hline 11 & Attending to project final defence on regular basis & 50 & 40 & 40 & 30 & 2.69 & Agreed \\
\hline 12 & Attending workshops and conferences regularly & 72 & 68 & 20 & 0 & 3.33 & Agreed \\
\hline 13 & Supervising students on community service & 50 & 50 & 30 & 30 & 2.75 & Agreed \\
\hline 14 & Serves as a coordinator of any programme & 35 & 44 & 58 & 25 & 2.58 & Agreed \\
\hline 15 & Serves as a director of a programme & 30 & 40 & 40 & 50 & 2.31 & Agreed \\
\hline 16 & Serves as examination officer & 59 & 48 & 31 & 22 & 2.9 & Agreed \\
\hline 17 & Serves as student's advisers & 66 & 60 & 24 & 30 & 3.26 & Agreed \\
\hline 18 & Serves as a member of any committee & 40 & 35 & 50 & 35 & 2.5 & Agreed \\
\hline 19 & Continuous writing and publishing & 88 & 72 & 0 & 0 & 3.55 & Agreed \\
\hline
\end{tabular}


The table revealed that all the items had mean above the criterion mean of 2.5. This shows that lecturers engage in various workloads such as; planning what to teach on regular basis, teaching very large classes, conducting test and examination for large number of classes, Invigilating students examinations under tension due to poor accommodation, producing students' results within limited time, attending to staff meetings on regular basis, Attending seminars for students, supervising undergraduate's projects within limited time, Supervising post graduate projects within limited time, attending to project proposal defence on regular basis, attending to project final defence on regular basis, attending to project final defence on regular basis, attending workshops and conferences regularly, supervising students on community service, Serves as a coordinator of any programme, serves as a director of a programme, serves as examination officer, Serves as student's advisers, Serves as a member of any committee, Continuous writing for publishing.

\subsection{Research Question 2}

What is the extent of influence of workload on job performance as perceived by lecturers?

Table 2. Mean analysis of lecturers' perception on the extent of influence of workload their job performance

\begin{tabular}{|l|l|l|l|l|l|l|l|}
\hline $\mathbf{S} / \mathbf{N}$ & \multicolumn{1}{|c|}{ Items } & SA & $\mathbf{A}$ & $\mathbf{D}$ & $\mathbf{S D}$ & $\mathbf{X}$ & \multicolumn{1}{|c|}{ Decision } \\
\hline 1 & Much Workload leads to stress resulting in lack of concentration to perform & 90 & 30 & 40 & 0 & 3.31 & High extent \\
\hline 2 & $\begin{array}{l}\text { Excess work leads to deviant behavior among lecturers which leads to poor } \\
\text { relationship with students }\end{array}$ & 80 & 54 & 23 & 13 & 3.38 & High extent \\
\hline 3 & $\begin{array}{l}\text { Doing too many other works leads to being absent in the class } \\
\text { Too many work leads to stress that reduces efficiency, competence and } \\
\text { effectiveness among lecturers }\end{array}$ & 50 & 48 & 38 & 24 & 2.78 & High extent \\
\hline 5 & $\begin{array}{l}\text { Excess workload leads to burnout which renders lecturers physically and } \\
\text { emotionally exhausted to perform }\end{array}$ & 74 & 55 & 21 & 10 & 3.08 & High extent \\
\hline 6 & $\begin{array}{l}\text { Excess workload leads to prolonged stress that cause depression among } \\
\text { lecturers }\end{array}$ & 53 & 68 & 30 & 9 & 3.03 & High extent \\
\hline 7 & $\begin{array}{l}\text { Excess workload leads to stress that causes work related disease such as } \\
\text { restlessness and anxiety which renders lecturers incapacitated }\end{array}$ & 71 & 59 & 20 & 10 & 3.19 & High extent \\
\hline 8 & $\begin{array}{l}\text { Workload with limited deadline for completion causes stress leading to } \\
\text { frustration among lecturers }\end{array}$ & 60 & 50 & 16 & 2.7 & High extent \\
\hline
\end{tabular}

The table revealed that all the items had mean above the criterion mean of 2.5 . This showsthat the influence of workload on lecturers' performance is high. This revealed that much workload leads to stress resulting in lack of concentration to perform, excess work leads to deviant behavior among lecturers which leads to poor relationship with students, doing too many other works leads to being absent in the class, too many work leads to stress that reduces efficiency, competence and effectiveness among lecturers, excess workload leads to burnout which renders lecturers physically and emotionally exhausted to perform, excess workload leads to prolonged stress that cause depression among lecturers, excess workload leads to stress that causes work related disease such as restlessness and anxiety which renders lecturers incapacitated, workload with limited deadline for completion causes stress leading to frustration among lecturers.

\subsection{Research Question 3}

What coping strategies can be adopted to manage workload among lecturers in universities?

Table 3. Mean analysis on the coping strategies to manage workload among lecturers in universities

\begin{tabular}{|l|l|c|c|c|c|c|l|}
\hline $\mathbf{S} / \mathbf{N}$ & \multicolumn{1}{|c|}{ Items } & SA & $\mathbf{A}$ & $\mathbf{D}$ & $\mathbf{S D}$ & $\mathbf{X}$ & Decision \\
\hline 1 & Manage time appropriately & 75 & 49 & 26 & 10 & 3.18 & Agreed \\
\hline 2 & Prioritise the various works & 54 & 55 & 34 & 17 & 2.91 & Agreed \\
\hline 3 & Always taking a short break in whatever work one does & 60 & 68 & 22 & 10 & 3.11 & Agreed \\
\hline 4 & Appointment of lecturers into various offices should be well distributed & 55 & 70 & 30 & 5 & 3.09 & Agreed \\
\hline 5 & Analysis of one's responsibilities adequately & 49 & 95 & 30 & 6 & 3.04 & Agreed \\
\hline 6 & $\begin{array}{l}\text { Adequate payment of overtime allowance to lecturers to enhance health check } \\
\text { ups }\end{array}$ & 56 & 88 & 16 & 0 & 3.25 & Agreed \\
\hline 7 & Earned academic allowance should be regularly paid to lecturers & 70 & 70 & 20 & 0 & 3.31 & Agreed \\
\hline 8 & $\begin{array}{l}\text { Lecturers who already occupied in a position should not be engaged in more } \\
\text { other appointments }\end{array}$ & 60 & 20 & 20 & 3.00 & Agreed \\
\hline 9 & $\begin{array}{l}\text { Efforts to employ more lecturers to avoid one lecturer teaching very large } \\
\text { classes }\end{array}$ & 71 & 89 & 10 & 0 & 3.44 & Agreed \\
\hline 10 & Lecturers should learn to say no when they are to face with so many works & 78 & 65 & 10 & 7 & 3.34 & Agreed \\
\hline & Aggregate Mean & & & & & Agreed \\
\hline
\end{tabular}


The table revealed that all items had mean scores above criterion mean of 2.5. This showed that the coping strategies for managing workload are; manage time appropriately, prioritize the various works, always taking a short break in whatever work one does, appointment of lecturers into various offices should be well distributed, analysis of one's responsibilities adequately, adequate payment of overtime allowance to lecturers to enhance health checkups of the health effect due to workload, earned academic allowance should be regularly paid to lecturers, Lecturers who already occupy a position should not be engaged in more other appointments, efforts to employ more lecturers to avoid one lecturer teaching very large classes. The result shows that the lecturers agreed with all the items as strategies to cope with workload.

\section{SumMary OF FINDINGS}

- Lecturers perform so many tasks that are heavily loaded, which include: planning what to teach on regular basis, teaching very large classes, conducting test and examination for large number of students, invigilating students examinations under tension due to poor accommodation, producing students' results within limited time, attending to staff meetings on regular basis, Attending seminars for students, supervising undergraduate and graduate students' projects within limited time

- The extent of influence of workload as perceived by lecturers on their performance is high.

- The coping strategies to manage workload and work related stress among others are; managing time appropriately, prioritizing the various works, always taking a short break in whatever work one does, appointment of lecturers into various offices should be well distributed, analysis of one's responsibilities adequately, adequate payment of overtime allowance to lecturers to enhance health checkups on regular basis, earned academic allowance should be regularly paid to lecturers, Lecturers who already occupy a position should not be engaged in more other appointments, more lecturers should be employed to reduce workload on the old ones.

\section{DISCUSSIONS OF FINDINGS}

\subsection{Workloads}

The study revealed that lecturers engage in various workloads such as; planning what to teach on regular basis, teaching very large classes, conducting test and examination for large number of classes, Invigilating students examinations under tension due to poor accommodation, producing students' results within limited time, attending to staff meetings on regular basis, Attending seminars for students, supervising undergraduate's projects within limited time, Supervising post graduate projects within limited time, attending to project proposal defence on regular basis, attending to project final defence on regular basis, attending to project final defence on regular basis, attending workshops and conferences regularly, supervising students on community service, Serves as a coordinator of any programme, serves as a director of a programme, serves as examination officer, Serves as student's advisers, Serves as a member of any committee, Continuous writing for publishing. The implication is that on regular basis lecturers are faced with diversities of work that could affect their performance. On the issue of conducting test and examination of very large class size the Elementary Teachers Federation of Ontario (2011), reports that students' assessment in the recent years has become more complex and more time consuming and a major source of stress. On the issue of accomplishing most works with limited time, Ejiogu \& Aderounmu in Njoku (2014) noted that academic staffs devote more attention to interacting with others, meetings, meeting deadline pressures and schedules, this backfires on their health. Ekechukwu (2010), who worked on burnout among policemen who are also overloaded with routine tasks, opined that, without proper scheduling and spacing out of tasks to people who are involved in people oriented services like lecturers, there will always be health challenges that will erode the joy of work and vitality. This was further stressed by Maslach (2003), who said that job burnout due to work overload evokes images of final flickering flames of a charmed empty shell of dying embers and cold, gray ashes. This images express what men and women teaching in Nigerian universities go through in their work place. Healthy enthusiastic men and women employed to teach and dispense knowledge to the future generation after a few years into the job, looses interest and enthusiasm and the work becomes a drudgery as a result of work overload, they dread going back to the same work daily. 
The study also revealed that the influence of workload on lecturers' performance is high. The study revealed that much workload leads to stress resulting in lack of concentration to perform, deviant behavior among lecturers which leads to poor relationship with students, doing too many other works at same time leading to occasional absence in the class, too many work leading to stress that reduces efficiency, competence and effectiveness. The study also revealed that excess workload leads to burnout which renders lecturers physically and emotionally exhausted to perform. This leads to prolonged stress that causes depression and other related diseases among lecturers, which render lecturers incapacitated. It also revealed that workload with limited deadline for completion causes stress leading to frustration among lecturers. The implication of the result shows that most of the stress workers have are as a result of much work. Stress is always accompanied with huge problems which make workers in effective in performing their works. The result agrees with Njoku (2014) who outlines some effects of job related stress as lapses in memory, loss of concentration, indecision, inability to get task completed, and the like. The result also agrees with Ivancevich, Konopaske \& Matreson (2005) who reported that prolonged exposure to social, physical and psychological workload leads to burnout which renders workers to be physically and emotionally exhausted. Orluwene (2013) reports that excess workload leads to poorer teaching performance and it leads to the development of deviant or anti social behaviour which include; lateness to work, poor decision making, bad judgment, nagging, procrastination, physical violence etc. In fact much work load is never a friend to the worker. The need to handle it well cannot be overemphasized.

\subsection{Coping Strategies to Manage Workload and Work Related Stress}

The study revealed the coping strategies for managing workload such as: managing time appropriately, prioritizing the various works, always taking a short break in whatever work one does, appointment of lecturers into various offices should be well distributed, analysis of one's responsibilities adequately, adequate payment of overtime allowance to lecturers to enhance health checkups, earned academic allowance should be regularly paid to lecturers, Lecturers who already occupy a position should not be engaged in other appointments, efforts to employ more lecturers to avoid one lecturer teaching very large number of students. The result shows that the lecturers agreed with all the items as strategies to cope with workload. This agrees with Amadi (2014) who posits that job should be redesigned and rotated so that the duties will be limited for effective performance. It also agrees with Sarmiento (2002) who posits that one way of coping with stress arising from workload is to regularly engage in biofeedback which involves monitoring one's body functions so as to improve one's general health. The result also agrees with Mayo (2016) who also posits that coping with job related stress includes; organizing time properly, learning to say no, taking a vacation, listening to music among others. It also agrees with Orluwene (2014) who reportsedthat to cope with workload workers should make use of short breaks to take a walk or take a short break for lunch and refreshment and also creating a balanced schedule of responsibilities and daily tasks so that one is not burnout o. It also agrees with Susic (2009) who posits that the use of break to step away from work for some time is very essential because it gives the body soul and spirit a period of relaxation.

\section{CONClusion}

Teaching is a task that involves a lot of activities and its' accompany stress. A worker must work and live to work another day. The need therefore to manage the workloads of lecturer so that they can be effective in their performance cannot be overemphasized. The paper examined the workload performed by lecturers, extent of influence of workload on lecturer's job performance and strategies that can be adopted in managing workload. The findings showed that Lecturers perform so many works that are heavily loaded and that the workloads influence job performance of lecturers to a high extent as perceived by lecturers. The study also examined some coping strategies to manage workload among others are; manage time appropriately, prioritize the various work, always taking a short break or vacation. The study therefore concludes that if these strategies are adhered to by both lecturers and administrations, workload would be managed to a great extent and Nigerian lecturers would work and live to work again.

\section{RECOMMENDATIONS}

Based on the discussions of the findings of this study the following recommendations are made.

- Lecturers should learn to manage their time appropriately. They should stop procrastinating to avoid doing many works at the same time. 
- Lecturers should learn to prioritize the various works. They should learn how to do one thing first before another so that all are not done at the same time

- Lecturers should learn to take short break or vacation from time to time.

- Lecturers should learn to say no to some work so that it can be given to others, when he observes too many of them coming.

- Appointment of lecturers into various offices by the administration should be well distributed. No lecturer should be seen as the only cock that crows thereby making such lecturers to be overloaded with many tasks.

- Nigerian government should pay adequate overtime allowance to lecturers to enhance regular health checkups to stay healthy.

- Lecturers who already occupy a position should not be engaged in more other appointments.

- Universities should make efforts to employ more lecturers to avoid one lecturer teaching very large classes.

- Guidance counsellors should be employed to counsel lecturers on healthy lifestyles and psychological coping strategies.

- University authorities should establish counselling centres to take care of students and staff psychological wellbeing.

\section{REFERENCES}

[1] Amadi, G. N. (2011).Human stress and management. A realistic approach. Port Harcourt: Pan Unique Publishing Company

[2] American Psychological Association (2002). Warnings signs of trauma-related stress Washington D. C.

[3] Ekechukwu, R.O. (2010), Gender and Marital Status as Correlates of Burnout among Policemen: Implications for Counseling.

[4] Ingvarson, L, Heinhenz, E., Beavis, A., Barwick, H., Carthy, I. \& Wilkonson, J. (2005). Report on secondary teachers' workload. Retrieved from www.eedu.nin.edu.

[5] Ivancevich, J. M., konopaske, R. \& Matreson, M. T. (2005). Organizational behaviour and management. Toronto: McGraw Hill Irwin

[6] Maslach, C. (2003). Burnout, the Cost of Caring. Cambridge: Mylor Books.

[7] Mayo, C. (2016). Types of stress management. Retrieved from www.mayoclinic.org/prc20021046.

[8] Muchinsky, P. M. (2003). Psychology applied to work ( $7^{\text {th }}$ Ed.) Australia: Wadsworth Thomson.

[9] Njoku, C. (2014). Job related stress and work performance of academic administrators in tertiary institutions in Imo state. Unpublished Med dissertation, Rivers State University of Science and Technology

[10] Orluwene, G. W. (2013). Teachers' workload and stress management. In J. D. Asodike, J. M. Ebong, S. O. Oluwuo \&. N. M. Abraham (Eds). Contemporary administrative and teaching issues in Nigera schools. 138-152 Owerri: Alphabet Nigeria publishers.

[11] Sarmiento, R. F. (2002). Stress/anxiety/panic.Atlanta, G.A:Ivf.com Retrieved October 2017

[12] Susic, P. (2009). Stress management: what can you do? St Louis psychological and counseling information and referral. www.ipcir. Retrieved October 2017.

Citation: Osaat Dinah Sunday \& Ekechukwu Rosemary. " Managing Workload of Academic Staff for Job Effectiveness in Nigerian Universities: A Study of University of Port Harcourt in South-South Geopolitical Zone of Nigeria" International Journal of Humanities Social Sciences and Education (IJHSSE), vol 4, no. 11, 2017, pp. 102-108. doi: http://dx.doi.org/10.20431/2349-0381.0411013.

Copyright: () 2017 Authors. This is an open-access article distributed under the terms of the Creative Commons Attribution License, which permits unrestricted use, distribution, and reproduction in any medium, provided the original author and source are credited. 